\title{
Domestic cold pitched roofs in the UK: - effect of using different roof insulation materials
}

Article

Accepted Version

Essah, E. (2012) Domestic cold pitched roofs in the UK: effect of using different roof insulation materials. International Journal of Ventilation, 11 (3). pp. 281-286. ISSN 2044-4044 Available at https://centaur.reading.ac.uk/29836/

It is advisable to refer to the publisher's version if you intend to cite from the work. See Guidance on citing.

Published version at: http://www.ijovent.org/doi/abs/10.5555/2044-4044-11.3.281

Publisher: VEETECH Ltd; Allen Press

All outputs in CentAUR are protected by Intellectual Property Rights law, including copyright law. Copyright and IPR is retained by the creators or other copyright holders. Terms and conditions for use of this material are defined in the End User Agreement.

www.reading.ac.uk/centaur

\section{CentAUR}

Central Archive at the University of Reading 
Reading's research outputs online 


\title{
Domestic Cold Pitched Roofs in UK: - effect of using different roof insulation materials
}

\author{
Emmanuel A Essah \\ School of Construction Management and Engineering, University of Reading, Reading, RG6 6AW, UK
}

\begin{abstract}
The type and thickness of insulation on the topside horizontal of cold pitched roofs has a significant role in controlling air movement, energy conservation and moisture transfer reduction through the ceiling to the loft space. To investigate its importance, a numerical model using a HAM software package on a Matlab platform with a Simulink simulation tool has been developed using insitu measurements of airflows from the dwelling space through the ceiling to loft of three houses of different configurations and loft space. Considering typical roof underlay; bituminous felt and a vapour permeable underlay, insitu measurements of 3 houses were tested using calibrated passive sampling technique. Using the measures airflows, the effect of air movement on three roof insulations (i.e. fibreglass, cellulose and foam) was modelled to investigate their effect on energy losses and moisture transport. The thicknesses of the insulations have been varied but the ceiling airtightness and eaves gap size was kept constant. These instances were considered in order to visualize the effects of the changing parameters. In addition, two different roof underlay of varying resistances were considered and compared to access the influence of the underlay, if any, on energy conservation. The comparison of these insulation materials in relation to the other parameters showed that the type of insulation material and thickness, contributes significantly to energy conservation and moisture transfer reduction through the roof and hence of the building as a whole.
\end{abstract}

Keywords: Insulation material and thickness, moisture transfer, cold pitched roofs

\section{Introduction}

Building designs of the past were simple and took into account the environmental conditions (Loomans 1998). Until 1973, most countries in Europe did not have any effective policy for the efficient use of energy in building design because energy was inexpensive and readily available. However, after the oil crisis in 1973, the building industry evolved a great deal; many energy policies have been implemented as western countries became conscious of the concerns with the availability of energy (Santamouris et al. 1998). In recent years, concerns over the effect of global warming, have also given industries and policy makers a new impetus to develop energy saving initiatives.

This crisis resulted in the building industry gearing their activities towards the reduction of energy consumption which in buildings, was mainly used for heating and air conditioning, while neglecting impacts on the health and comfort of occupants in the building. This period then witnessed the growth of building research, and the inception of energy related building regulations leading to improved levels of thermal insulation, aimed at significantly reducing energy consumption. However, this was accompanied by an increase in the number of problems associated with moisture transfer (i.e. condensation and mould growth) and poor indoor air quality (IAQ) (Santamouris et al. 1998; Essah 2009).

The position of the thermal insulation relative to the roof underlay creates two basic categories of pitched roof designs, a) Warm pitched roofs and b) Cold pitched roofs. Cold pitched roofs, which constitute about $80 \%$ of domestic roofs in the UK, have insulation on the horizontal ceiling with an accessible, cold loft space above (Sanders 2006; Essah et al. 2006). While warm pitched roofs have the insulation below the slope of the roof just below the roof deck with small cavities above - the ceiling is not usually penetrated by services (Stirling 2002).

The reasonably low maintenance requirement of most pitched roofs, and the fact that they can be insulated to 
create warm or cold pitched roofs, strengthens the reasons for their selection in constructions of modern house designs. There is also a feeling in the UK that houses should have a pitched roof for aesthetic reasons (Essah 2009).

In this research cold pitched roofs are considered because the structural design, construction and build, with the insulation positioned horizontally on the ceiling boards below the inclined structure members, provides an accessible loft space. Its design which also integrates and underlay or sarking (i.e. Scottish build) which renders this type of construction very vulnerable to increases risk of condensation formation (Petherick 2001; Essah 2009).

Studies have established that unheated loft spaces above a well-insulated ceiling are vulnerable to moisture related damage (Sanders 1982). The higher the standard of thermal insulation used, the greater the risk of damage due to condensation formation. This is due to colder temperatures resulting in:

* Higher relative humidity (RH), which increases the moisture content of the hygroscopic materials.

* It also increases the risk of condensate accumulation on the underlay, which can run or drip onto the timbers and insulation (Essah 2009)

Roofs with an insulated ceiling plane are also common in West and North-European countries and in North America Holm and Lengsfeld (2007). As with studies by Sanders (2006) and Essah (2009) for UK houses, Holm and Lengsfeld (2007) support the fact that humid indoor air from subjacent heated rooms would reach the loft space via a roof access, usually a hatch with an access cover, or via gaps, light fittings, bath fans or partition walls. In the process it is frequently observed that the result is the formation of condensation water or frost on the underside of the sheathing. In their studies they conclude that roofs with insulation on the ceiling plane are more prone to moisture damages. Walker et al, (2005) in a study using homes in Alberta, argue in support that, the flow of air from the house to the roof space is very significant for the transport of heat and moisture.

From the point of view to mitigate the condensation on the membranes in the roof, one measure is to reduce air leakages from the insulated ceiling to the roof space (Sanders, 2006; Essah, 2009, Holm and
Lengsfeld, 2007). This view is also reiterated by studies conducted by Kaufmann, et al (2006).

These growing studies confirms the fact that these issues are not only limited to British houses but it extends to other parts of the world.

The research work discussed in this paper was undertaken to investigate the relevance of airflows on different types of roof insulation and their thickness and the possible energy benefits that may be achieved in cold pitched roofs. It also includes analysis obtained from modelling these parameters to investigate the risk of condensation formation, with respect to the insulation material installed.

\subsection{Essence of Research: Background}

Heat and water vapour passes from the house into the roof space by both conduction and diffusion through the ceiling and insulation as well as by air motion through gaps, cracks and holes in the ceiling. The rate of transfer depends on the amount of insulation, the presence or absence of vapour control layers and the number of unsealed penetrations through the ceiling (Essah, 2009). Energy losses due to ventilation and air infiltration accounts for a significant proportion of the total energy transfer from buildings (Liddament, 1996). In recent times, there is the growing need to restrict the rate at which heat energy is exchanged with the surroundings through the reduction of ventilation and infiltration, in order to maintain constant temperatures within buildings. Keeping heat inside a building over a long period conserves energy, eventually reducing cost of heating. Good thermal insulation would also reduce the transfer of heat into a building when the temperature outside is higher than the temperature inside (McMullan 2007). Eventually, some thermal insulation effectively limits conduction of heat, but has little or no resistance to air movement or diffusion of water vapour when laid uncompressed (Sanders 2006). Another benefit of thermal insulation is that it contributes to the reduction of the risk of surface condensation because the internal surfaces of the room are kept at a temperature which is above the dew-point of the air (McMullan 2007).

Fibreglass is one of the most commonly used building insulation material in pitched roofs of residential buildings in UK (Hokoi and Kumaran 1993), this continues to be the case in the building industry. However, there are other insulation materials which may have the same effect and worth investigating. Cellulose and foam insulation (two of many conventional insulation) have also been considered, to 
assess the capabilities of these material with that of fibreglass.

\subsection{Insulation Practises: Building Regulations and Standards}

For most practices and documented guidelines, within the UK climatic zone, reasonable levels of loft insulation for cold pitched roofs have normally been quantified to be between $150 \mathrm{~mm}$ to $200 \mathrm{~mm}$ (www.energysavingstrust.org.uk) and in other instances between $200 \mathrm{~mm}$ to $250 \mathrm{~mm}$ (Stirling 2002) while some home developers and other research organisations consider insulation in isolation and emphasise that increasing the insulation thickness is practically ideal for energy conservation, but with no specified limits. The Energy Savings Trust in UK recommends that, the optimum depth for loft insulation must be between $250 \mathrm{~mm}$ to $300 \mathrm{~mm}$; anything less than this should be topped up. Nevertheless, using more than $300 \mathrm{~mm}$ does not show any realistic benefits (www.energysavingstrust.org.uk).

Considering the different types of insulation materials (for instance, foam, glass wool, rock wool, cellulose, etc) (www.carbontrust.co.uk). Within volume 2 of UK's Building Regulations Part L, it is suggested that pitched roof insulation at ceiling level must have U-values of $0.16 \mathrm{~W} / \mathrm{m}^{2} . \mathrm{K}$ and for typical constructions; loft insulation of $250 \mathrm{~mm}$ must be provided (www.communities.gov.uk).
Arguably, from the recommended practises above, the appropriate depth of roof insulation is still subject to debate. It is evident that there is no distinct thickness defined for cold pitched roofs. As a result, the question still remains as to what extent the proposed varying thicknesses have been justified and what are the adverse effects of increasing or decreasing insulation thickness on energy conservation and other related issues (such as condensation formation); considering different roof configurations?

\subsubsection{Types and properties of roof insulation}

Ceiling insulation used in construction and especially in roofs is made from a wide variety of materials. These materials are designed for insulation of heat transfer at relatively low temperatures (McMullan 2007). A possible roof insulation material is categorised in Table 1.

In the context of this study, cellulose, solid foam and fibreglass would be considered. The thermal conductivity and density of conventional roof insulations required to achieve very low $\mathrm{U}$-values are listed as part of the input parameters in Table 2. The most highly insulated houses in the world have roof $\mathrm{U}$ values of between $0.10-0.15 \mathrm{~W} / \mathrm{m}^{2} / \mathrm{K}$, which is two to three times better than required in most cold-climate countries (Harvey 2010).

Table1. Categories of possible insulation materials

\begin{tabular}{|l|l|}
\hline Materials & Examples \\
\hline Flexible & Fibreglass, Mineral fibre insulation \\
\hline Loose fill & Cellulose, expanded polystyrene granules \\
\hline Materials formed on site & Foamed polyurethane (PUF) \\
\hline
\end{tabular}

Table 2 Summary of input properties of specific building materials considered for the model

\begin{tabular}{|l|l|l|l|l|l|}
\hline \multirow{2}{*}{ Parameters } & \multicolumn{5}{|c|}{ Roof Materials } \\
\cline { 2 - 6 } & $\begin{array}{l}\text { Roof } \\
\text { Deck }\end{array}$ & $\begin{array}{l}\text { Wooden } \\
\text { Panel }\end{array}$ & $\begin{array}{l}\text { Cellulose } \\
\text { Insulation }\end{array}$ & $\begin{array}{l}\text { Fibreglass } \\
\text { Insulation }\end{array}$ & $\begin{array}{l}\text { Foam } \\
\text { Insulation }\end{array}$ \\
\hline Dry density of the material $\left(\mathrm{kg} / \mathrm{m}^{3}\right)$ & 530 & 395 & 55 & 12 & 10 \\
\hline $\begin{array}{l}\text { Thermal conductivity of the dry } \\
\text { material }(\mathrm{W} / \mathrm{mK})\end{array}$ & 0.14 & 0.16 & 0.04 & 0.042 & $0.022-0.024$ \\
\hline Heat Capacity $(\mathrm{J} / \mathrm{kgK})$ & 1880 & 1880 & 1880 & 840 & 1400 \\
\hline Emissivity & 0.9 & 0.9 & 0.9 & 0.9 & 0.9 \\
\hline $\begin{array}{l}\text { Capillary moisture content by volume } \\
\left(\mathrm{kg} / \mathrm{m}^{3}\right)\end{array}$ & 680 & 758 & 900 & 780 & 560 \\
\hline
\end{tabular}

Source: Sanders 1996; Harvey 2010 


\subsection{Materials, Methods and Measurements}

In buildings with low energy design, the first and most immediate effective strategy for reducing dependence on primary energy sources (fossil fuel etc) is to increase energy efficiency and reduce usage where ever possible. The key is to have wellinsulated buildings designed to take advantage of passive heating and cooling. To achieve this, improving the thermal properties and airtightness of the building fabric is of major significance (www.energysavingtrust.org.uk).

Studies by Sanders (1982) and Essah and Sanders (2006) reveal that over $20 \%$ of heat in a building is lost through the roof, a fact which is acknowledged by The Carbon Trust, UK. In fact, it is estimated that insulating any loft spaces in a building could reduce heat loss by $25 \%$ to $30 \%$ of the total heat lost through the building fabric(www.carbontrust.co.uk).

Wherever practical, reducing the losses through the ceiling yields more direct benefit in energy savings, as a result, apart from ceiling off gaps and cracks in the sealing (Essah 2009), the choice and thickness of roof insulation is vital for a buildings energy conservation and reduction in condensation formation risks.
In this section, parameters and dimensions taken during the insitu measurements of the 3 buildings are presented. In addition, methods and measurements of airflows using a passive sampler and numerical simulations, using simulink a Matlab tool, are discussed.

\subsection{Characteristics of Buildings}

In order to investigate the effect of varying roof insulation, in-situ measurements of three existing houses were taken and modelled using HAM (Heat, Air and Mass transport) software. The modelled structure was based on measured dimensions obtained from standard duo pitched houses with typical cold pitched roof construction and masonry gable walls.

Though the model considers the entire dimensions of the house (as developed in the Matlab workspace), the graphical interface, shows only that of the roof.

Detailed explanations and model configurations have been explained by Essah et al (2009). Altogether three two storey buildings were considered. Insulation materials of varying thickness, was laid on the ceiling in conformity with requirements of the UK Building Regulations (see Table 3).

Other relevant characteristics of these houses and roofs are listed in Table 3.

Table 3 Characteristics of the three houses

\begin{tabular}{|c|c|c|c|}
\hline SPECIFICATIONS & HOUSE A & HOUSE B & HOUSE C \\
\hline \multicolumn{4}{|l|}{ House } \\
\hline Age (years) & $\approx 21$ & $\approx 16$ & $\approx 4$ \\
\hline Style (Two Storey) & Semi-detached & Detached & Terraced \\
\hline $\begin{array}{l}\text { Volume }\left(\mathrm{m}^{3}\right) \\
\quad \text {-working volume }\end{array}$ & 65.4 & 92.9 & 108.3 \\
\hline \multicolumn{4}{|l|}{ Roof } \\
\hline Rafters & Steel & Timber & Timber \\
\hline Pitch (degrees) & $15^{\circ}$ & $30^{\circ}$ & $30^{\circ}$ \\
\hline Area of Ceiling $\left(\mathrm{m}^{2}\right)$ & $\approx 52.9$ & $\approx 57.0$ & $\approx 43.2$ \\
\hline Volume $\left(\mathrm{m}^{3}\right)$ & 26.4 & 55.8 & 45.4 \\
\hline $\begin{array}{l}\text { Height of roof from ceiling floor } \\
\text { (m) }\end{array}$ & $\approx 0.89$ & $\approx 1.93$ & $\approx 1.85$ \\
\hline Insulation Thickness (mm) & $\approx 300$ & $\approx 250$ & $\approx 250$ \\
\hline Underlay & Bituminous Felt & Bituminous Felt & Bituminous Felt \\
\hline Ventilators & Eaves $(10 \mathrm{~mm})$ & Eaves $(10 \mathrm{~mm})$ & $\begin{array}{l}\text { Eaves }(10 \mathrm{~mm}) \\
\text { Ridge }(5 \mathrm{~mm})\end{array}$ \\
\hline Sarking Boards & Plywood & Fibreboard & Oriented Strand Board (OSB) \\
\hline
\end{tabular}




\subsection{Airflow measurements: SPME Passive Sampler}

In-situ measurements were carried out in three houses all with cold pitched roofs and in different parts of Glasgow. During the period of measurements, two houses were occupied (i.e. houses 2 and 3) while the other was not (the occupants were on holiday). All three houses had different roof configurations (Table 3). One particular configuration that stood out had an unusual design; with steel rafters, plywood sarking and a very low pitch $\left(15^{\circ}\right)$ so that the height from the ceiling to the apex was only one metre.

Almost all the eaves gaps were blocked by the thickness of the insulation. A lot of mould was identified on all surfaces of the plywood sarking in this loft space, though upon visual inspections there were no signs of condensation. Measurements of the ventilation rates in the houses were performed using a Solid-phase microextraction (SPME) fibre a passive sampling technique. The design, calibration and validation of these techniques have been discussed and well documented in a research by Essah and Sanders (2010). Each measurement was performed over two days.
Five SPME fibres were used to monitor conditions in each roof while another five were used in various locations within the house. Toluene and ortho-xylene (VOCs) were introduced into the house and roof respectively, with, three $100 \mathrm{ml}$ beakers evenly spaced and placed in the roofs and three beakers were also placed at significant points in the houses. This was done to follow the measurement protocol outlined by Essah and Sanders (2010) and to ensure that the working volumes in the roof and house were well mixed ensuring even distribution of VOC concentrations.

During measurements, airflows $\left(\mathrm{X}_{\mathrm{hr}}\right)$ from the house $(\mathrm{h})$ to the roof (r) obtained from the SPME fibre technique were analysed. From data collected, using SPSS a statistical package, ventilation rates $\left(\beta_{\mathrm{r}}\right)$ and airflows are summarised by relations in Table 4 . On the whole, measurements and analysis varied between $20 \mathrm{~m}^{3} / \mathrm{h}-$ $35 \mathrm{~m}^{3} / \mathrm{h}$.

The heights flows were recorded in House A. This was evident as upon visual inspection there were lots of cracks through the ceiling to the loft space with a partly opened hatch even when sealed (i.e. for House A). For the purpose of this study, all houses were modelled for airflows of $20 \mathrm{~m}^{3} / \mathrm{h}$.

Table 4: Summary equations obtained from SPME passive sampler

\begin{tabular}{|l|l|l|}
\hline & Ventilation Rates $\left(\beta_{\mathrm{r}}\right)$ & Airflows $\left(\mathrm{X}_{\mathrm{hr}}\right)$ \\
\hline House A & $\beta_{r}=10.27+1.24 * v-0.19 * T_{e}-0.66 * T_{h}$ & $X_{h r}=-36.33+4.14 * v+13.2 *\left(T_{h}-T_{e}\right)$ \\
\hline House B & $\beta_{r}=-6.28+1.80 * v-0.38 *\left(T_{r}-T_{e}\right)$ & $X_{h r}=-6.55+1.77 * v+0.80 *\left(T_{h}-T_{r}\right)$ \\
\hline House C & $\beta_{r}=0.11+0.24 * v-0.06 *\left(T_{r}-T_{e}\right)$ & $X_{h r}=19.58+0.26 * v+0.021 *\left(T_{h}-T_{r}\right)$ \\
\hline
\end{tabular}

Where $\boldsymbol{v}$ is the wind speed in $\mathrm{m} / \mathrm{s}$ and $\boldsymbol{T}_{\boldsymbol{e}}, \boldsymbol{T}_{\boldsymbol{h}}$ and $\boldsymbol{T}_{\boldsymbol{r}}$ are the external, house and roof temperatures respectively, in ${ }^{\circ} \mathrm{C}$.

The height of the loft space from the ceiling to the apex and the pitch of House A (Table 3) may have influenced the extent to which air flows in and out of the loft space. House A which has the unusual roof design and configuration with steel rafters (see Figure 1), plywood sarking, a shallow loft space coupled with the fact that there was blocked venting since all the eaves was covered by the thickness of the insulation $(300 \mathrm{~mm})$ makes it susceptible to condensation formation risk.
It must be noted that, in this instance it is the lack of a ventilation path that increases condensation risk.

Though there were no visible signs of condensation but for spots of mould growth over sections of the plywood sarking as illustrated in Figure 2. As with most UK cold pitched houses; most services passes through the ceiling to the roof, as evident in Figures 1 and 3. This provides possible unsealed gaps and cracks around the fittings which is always a major source for air infiltration. 


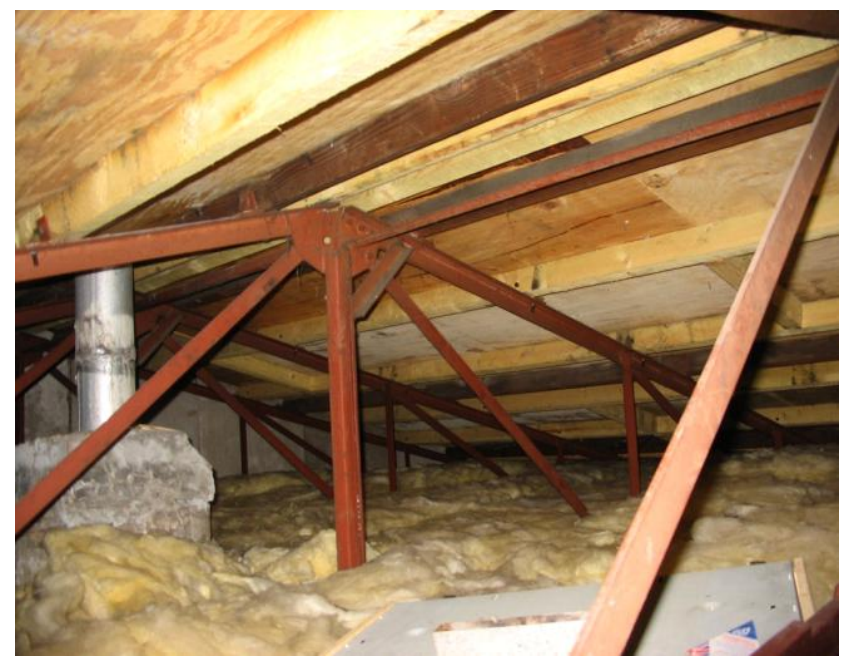

Figure. 1. Internal configuration of House A with steal rafters

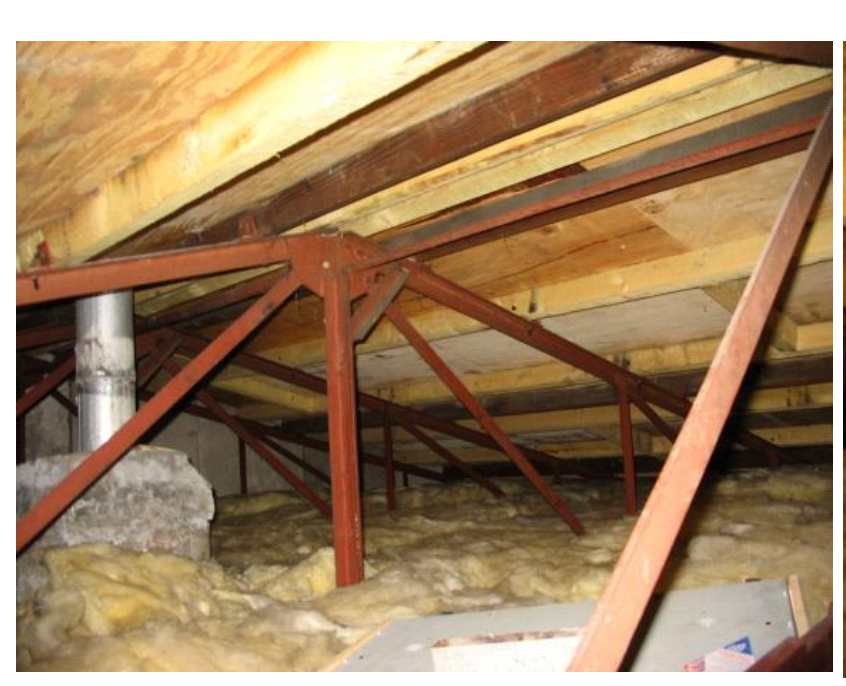

House B

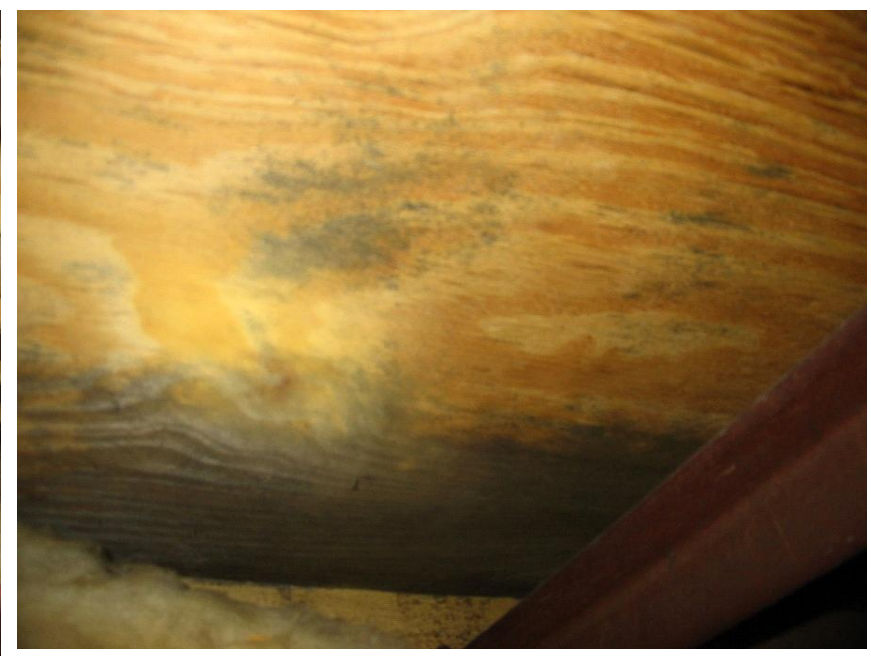

Figure. 2 Scattered black spots of mould growth on a section of the plywood sarking

\section{.}

Figure 3. Internal configuration of Houses B and $C$ with evidence of the penetration of services

\subsection{Numerical Simulations}

The physical state of any building envelope is influenced by heat, air and moisture transfer. To assess these, temperature levels, heat flows and moisture conditions must be predicted (Hagentoft 2001). However, this can only be attained by collecting data on conditions inside and outside buildings (Sanders 1996), which until now has always been experimentally difficult to achieve. Modelling with Heat, Air and Moisture (HAM) modelling packages is increasingly becoming an alternative solution. In this paper, one of such package; HAM-Tools, has been used to investigate the effects of insulation materials in the roof structures on condensation formation risks and the energy efficiency.

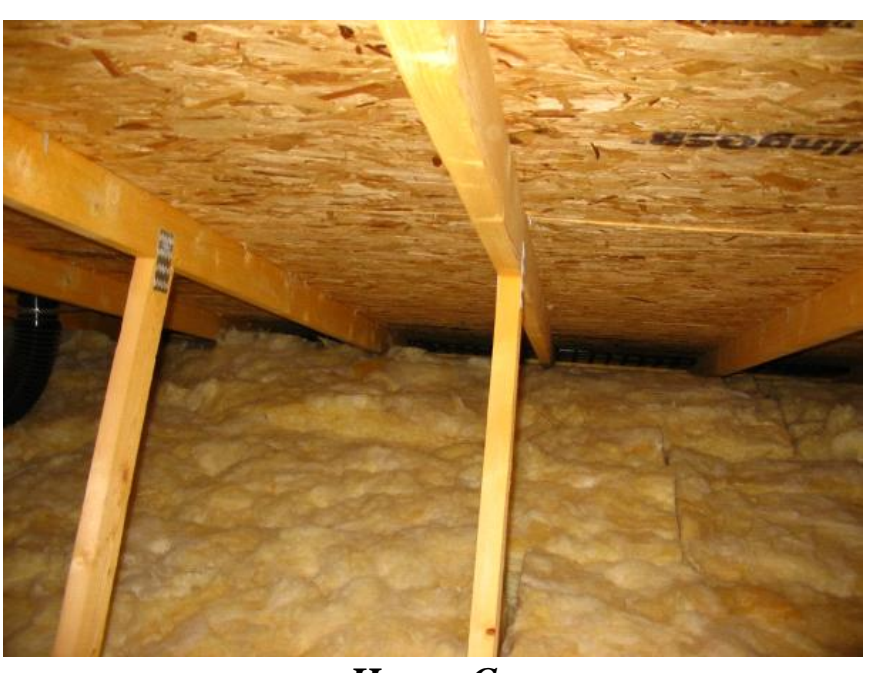

House C 
the airflow model applies to the flows into the house, the dimensions of the house are important for these airflow calculations. There is no HAM model of the house and the indoor climate is assumed to be dependent on the outdoor air temperature, as specified in Annex C of BS EN 15026 (2007).

If this is not assumed, it would be difficult to compare the cases since the indoor climate will change from case to case, depending on the airflow rate through the house. A year of hourly meteorological data obtained from weather stations was used in the investigation.

This included ambient temperature, relative humidity, wind speed, wind direction, long-wave radiation and solar irradiation (i.e. global, direct and diffuse). Apart from the VPU, material properties were obtained from the final report on material properties from IEA Annex 24 (Kumaran, 1996).

Detailed input values such as the sorption isotherm, vapour permeability and moisture conductivity which are all dependent on relative humidity and moisture content in the materials are made up of strings of values, which were referenced from the Annex 24 report (Essah et al., 2008). A summary of the relevant materials of each element as input into the model is shown in Tables 2 and 5. Table 2 shows characteristics of different roof materials required for $\mathrm{U}$-values of between $0.10-0.15 \mathrm{~W} / \mathrm{m}^{2} / \mathrm{K}$.

Modelling the effects of roof materials, the formation of condensation risk and energy benefits is currently the ideal option to visualise the performance of the building fabric and materials. This is because measuring condensation is practically difficult if not impossible. In present day buildings, the main method of heat transfer is by conduction, however, convection and radiation mechanisms are also relevant (McMullan 2007).

The losses as accounted for through the ceiling (Figure 4) to the roof are categorized in two separate forms;

- One is due to the ventilation (leakage) losses through the eaves and ceiling.

- The other due to the transmission losses (i.e. by conduction).

Table 5 Details of input parameters of elements used in the model assembly

\begin{tabular}{|l|l|}
\hline Parameters & Value(s) \\
\hline Volume of roof $\left(\mathrm{m}^{3}\right)$ & as in Table 3 \\
\hline Volume of house $\left(\mathrm{m}^{3}\right)$, usable space during measurements & as in Table 3 \\
\hline $\begin{array}{l}\text { Convective vapour transfer coefficient for outdoor and indoor surface of gables } \\
\left(\mathrm{kg} / \mathrm{sm}^{2} \mathrm{~Pa}\right)\end{array}$ & $2 * 10^{-9}, 10^{-50}$ \\
\hline $\begin{array}{l}\text { Convective vapour transfer coefficient for outdoor and indoor surface of roof } \\
\left(\mathrm{kg} / \mathrm{sm}^{2} \mathrm{~Pa}\right)\end{array}$ & $2 * 10^{-7}, 2^{*} 10^{-8}$ \\
\hline $\begin{array}{l}\text { Convective vapour transfer coefficient for outdoor and indoor surface of ceiling } \\
\left(\mathrm{kg} / \mathrm{sm}^{2} \mathrm{~Pa}\right)\end{array}$ & $2 * 10^{-8}, 2^{*} 10^{-8}$ \\
\hline $\begin{array}{l}\text { Combined (i.e. convective and radiative) heat transfer coefficient for outdoor and } \\
\text { indoor surfaces of the ceiling }\left(\mathrm{W} / \mathrm{m}^{2} \mathrm{~K}\right)\end{array}$ & 8,8 \\
\hline $\begin{array}{l}\text { Combined heat transfer coefficient for outdoor and indoor surfaces of roof and gables } \\
\left(\mathrm{W} / \mathrm{m}^{2} \mathrm{~K}\right)\end{array}$ & $29.3,8$ \\
\hline $\begin{array}{l}\text { Initial Conditions (temperature, relative humidity, air pressure) } \\
{\left[{ }^{\circ} \mathrm{C}, \%, \text { Pa] }\right.}\end{array}$ & $20,70,0$ \\
\hline View factor with the sky (for long-wave radiation exchange) for roof & 0.8 \\
\hline View factor with the sky (for long-wave radiation exchange) for sides & 0 \\
\hline Long-wave Shading of roof $(\%)$ & 20 \\
\hline Long-wave Shading of sides $(\%)$ & 100 \\
\hline
\end{tabular}

Source: Essah et al, 2009 


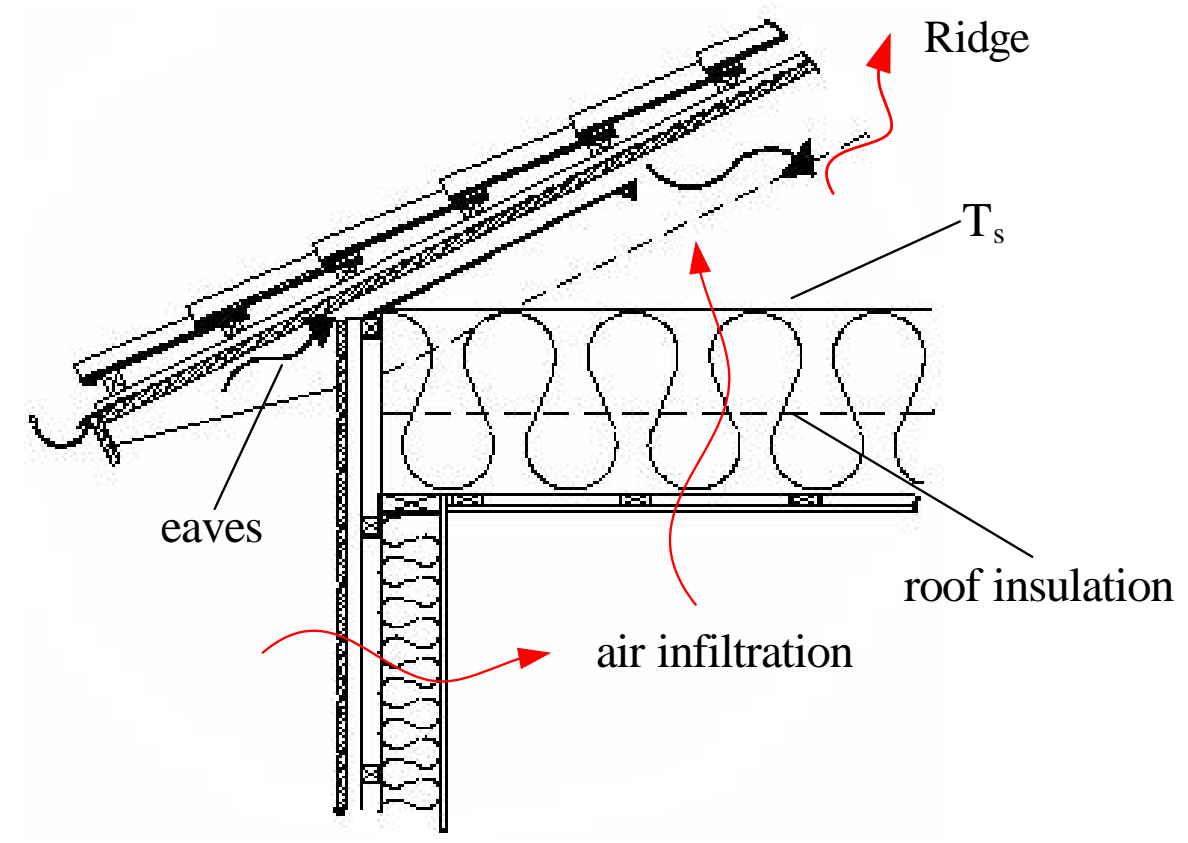

Figure 4. Cross-section of a pitched roof insulated at the ceiling level showing directions of air movement

Within the developed model, the following equations were integrated to determine the losses.

\section{Leakage Losses $\left(\mathrm{Q}_{\mathrm{L}}\right)$}

The density of dry air $\left(\boldsymbol{\rho}_{\text {air }}\right)$ as defined and used in this model is

$$
\rho_{\text {air }}=\frac{P}{R \cdot T}
$$

where

$\boldsymbol{P}$ is atmospheric pressure, $101325 \mathrm{~Pa}$

$\boldsymbol{R}$ is the specific gas constant of dry air, $287.05 \mathrm{Jkg}^{-1}$ $\mathrm{K}^{-1}$

$\boldsymbol{T}$ is the Temperature, in $\mathrm{K}$

Considering the volumetric flow rate $\left(\boldsymbol{\Gamma}_{\boldsymbol{a}}\right.$ in $\left.\mathrm{m}^{3} / \mathrm{s}\right)$ through the roof and the attic floor, then

$\boldsymbol{m}_{\boldsymbol{a}}$ is the mass flow rate, in $\mathrm{kg} / \mathrm{s}$, given by the relation below.

$$
m_{a}=\Gamma_{a} \rho_{a}
$$$$
Q_{L}=m_{a} C_{P}\left(T_{e x t}-T_{a t t i c}\right) \text {, in } \mathrm{W}
$$

where

$C_{P}$ is the specific heat capacity of air, $1012 \mathrm{~J} \mathrm{Jkg}^{-1}$ $\mathrm{K}^{-1}$

$\boldsymbol{T}_{\text {ext }}$ is the ambient (external) temperature, in $\mathrm{K}$

$\boldsymbol{T}_{\text {attic }}$ is the attic temperature, in $\mathrm{K}$
Transmission Losses $\left(\mathrm{Q}_{\mathrm{T}}\right)$

This takes into account the convective and radiation heat losses.

That is

$$
Q_{T}=q_{c}+q_{r}, \text { in } \mathrm{W} / \mathrm{m}^{2}
$$

For convective $\left(\boldsymbol{q}_{\boldsymbol{c}}\right)$ heat

$$
q_{c}=h\left(T_{s}-T_{e x t}\right)
$$

$\boldsymbol{T}_{s}$ is the surface temperature of the insulation material $\boldsymbol{h}$ is the convection heat transfer coefficient

The net radiant energy $\left(\boldsymbol{q}_{\boldsymbol{r}}\right)$ absorbed by the surface originates from the incoming solar radiation (direct and diffuse) and the long wave radiation exchange with surroundings;

$q_{r}=\alpha_{\text {sol }} .\left(I_{d i r}+I_{d i f f}\right)+\left(I_{l w}-\varepsilon \sigma T_{\text {surf }}^{4}\right)$

The total transmission losses is therefore given by the relation below

$$
Q_{T}=h\left(T_{s}-T_{e x t}\right)+\left[\alpha_{s o l} .\left(I_{d i r}+I_{d i f f}\right)+\left(I_{l w}-\varepsilon \sigma T_{s}^{4}\right)\right]
$$

where

$\varepsilon$ is the material emissivity

$\boldsymbol{\alpha}_{\text {sol }}$ solar absorption

$\boldsymbol{\sigma}$ is the Stefan-Boltzmann constant, $5.67 \times 10^{-8}$ $\mathrm{W} /\left(\mathrm{m}^{2} \mathrm{~K}^{4}\right)$ 
$\boldsymbol{I}_{\text {dir }}$ is the direct solar radiation

$\boldsymbol{I}_{\text {diff }}$ is the diffuse solar radiation

$\boldsymbol{I}_{l w}$ is the long wave radiation exchange with the surroundings

Also, integrated within the model are algorithms to estimate the amount of condensate that forms in the roof space when fitted with different underlays of known resistance. Condensation and moisture transfer algorithms have been extensively discussed by Essah et al (2009).

\subsection{Results and Analysis}

Considering House A, the model has been used to assess the general trend of relative humidity $(\mathrm{RH})$ in the loft space at an insulation thickness of $250 \mathrm{~mm}$. Figure 5 shows the RH, when the specified airflows are modelled for eaves gap sizes of $10 \mathrm{~mm}$ and $0 \mathrm{~mm}$ (where possible completely sealed). Both curves follow the trends that would be expected for the varying seasonal changes, with more RH during winter than summer. Notably, the model is observed to be responding to air movement through the eaves as it demonstrates a more variable distribution for a $10 \mathrm{~mm}$ eaves gap.

In another study, for a $10 \mathrm{~mm}$ eaves gap, two different roof underlays were located separately between the assemblies.
These were; a bituminous felt (vapour resistance of 200 $\mathrm{MNs} / \mathrm{g}$ ) and a vapour permeable underlay (Roofsheildvapour resistance of $0.09 \mathrm{MNs} / \mathrm{g}$ ) were compared. As illustrated in Figure 6, it is evident that even though the trend of RH in the loft space is similar, RH levels are relatively low between the months of May till November when the VPU is installed.

However, during the winter and spring months (between mid-November to end of March), RH levels are high in both instances but more so with the VPU on some possible cold days. It would have been expected that the VPU would allow moisture flow out of the loft space and reduce RH levels during the winter period. Nevertheless, in this study this is not the case.

The fact that moisture levels are high (i.e. high RH for both eaves gap sizes) during the winter months supports the fact that, for the VPU to work properly, without the risk of condensate accumulation on the underlay, the rate at which moisture vapour enters the roof from rooms below must be equal to the rate at which it leaves through the underlay (NHBC, 2006; Essah et al. 2009). As a result, because of the high RH levels during winter months the model confirms the argument made above. It is however clear that, the effect of adequate ventilation into the roof space to reducing humidity levels cannot be over emphasised.

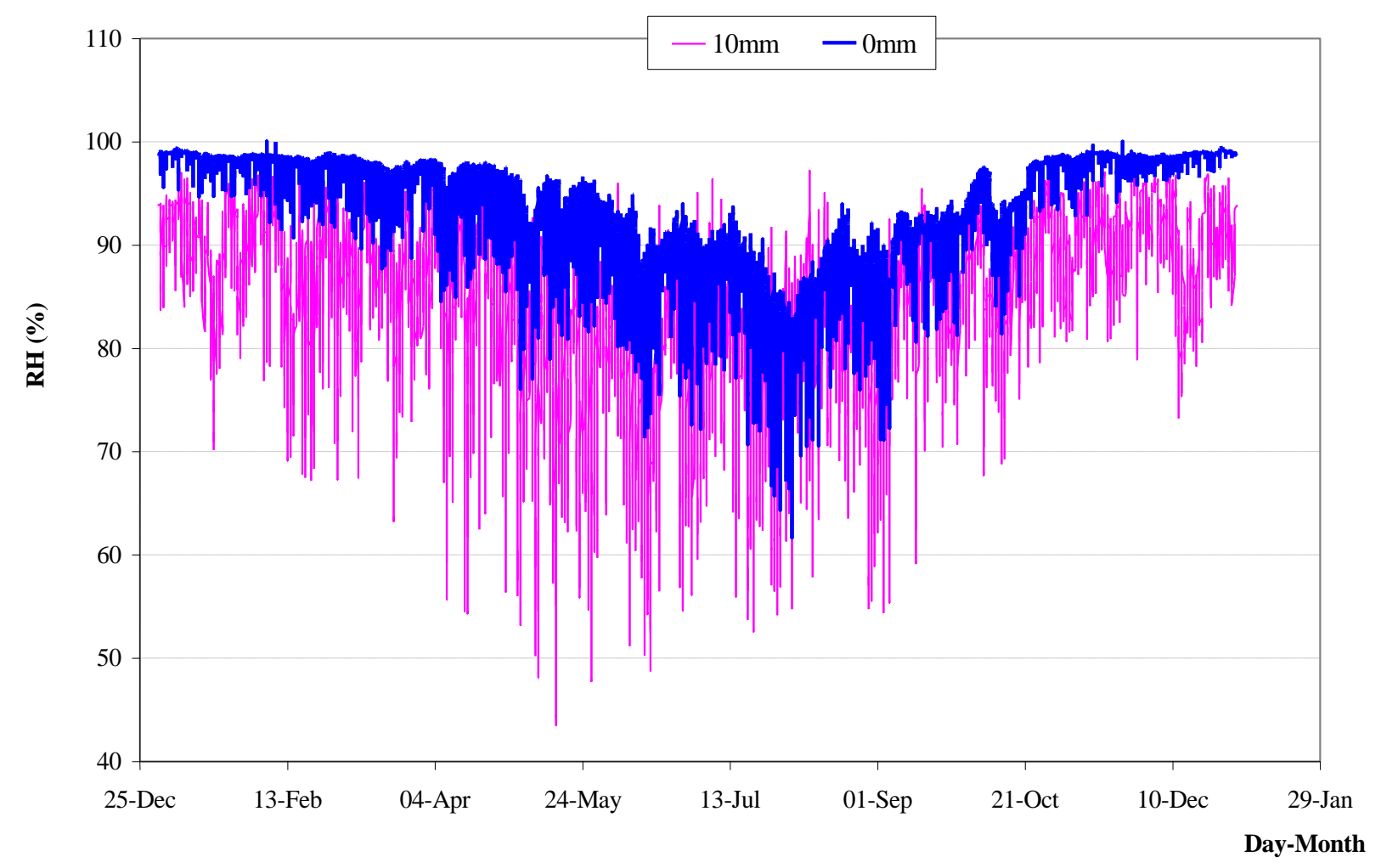

Figure 5. RH distributions in the loft space for two eaves gap sizes 


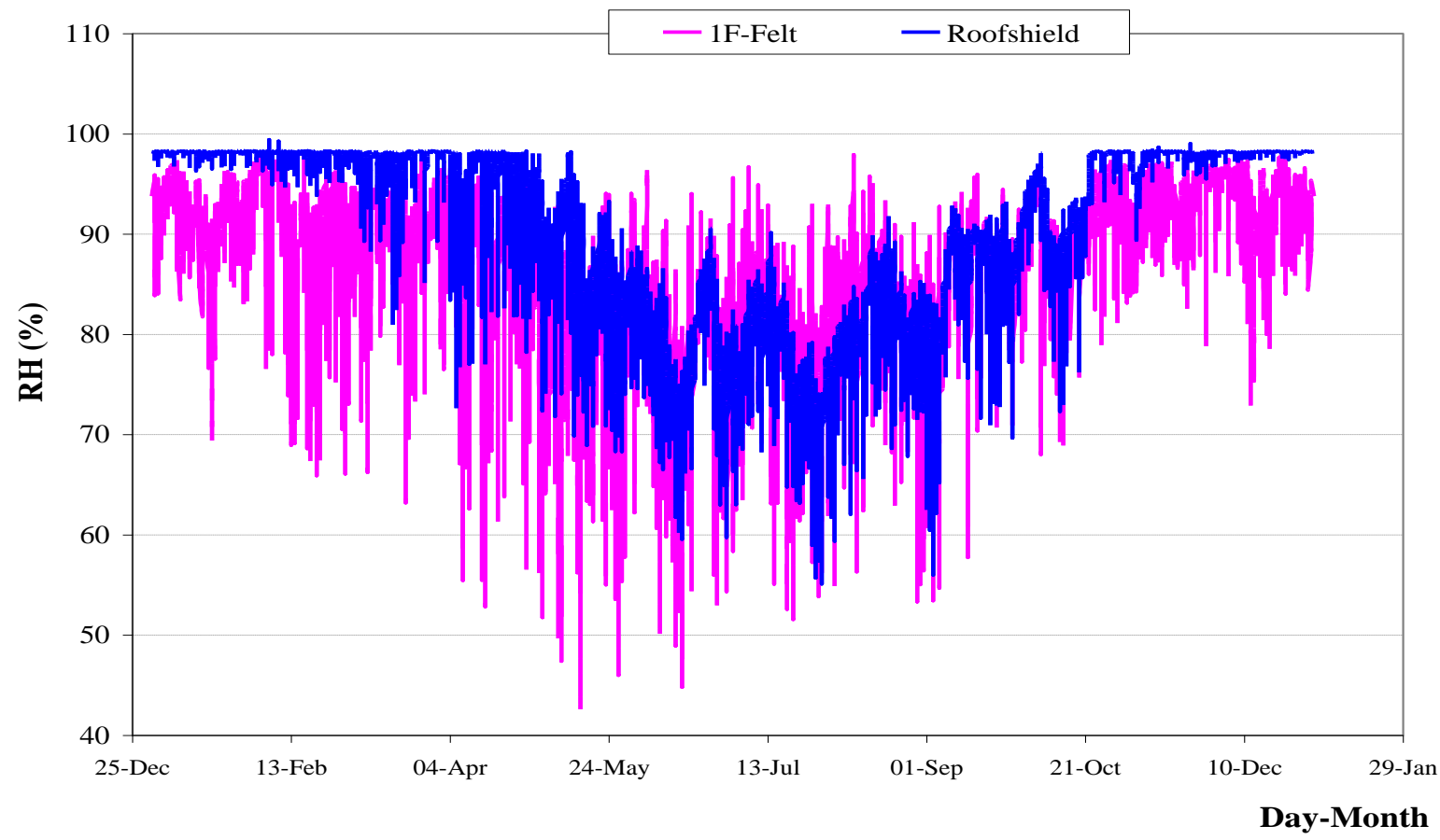

Figure 6. RH distribution in the loft space for the same eaves gap size $(10 \mathrm{~mm})$ but varying roof underlay

\subsection{Cases Investigated}

Case studies were designed to investigate the effects of three different roof insulation materials (i.e. Foam, Cellulose and Fibreglass) on the accumulation of condensate and energy benefits in three cold pitched roofs.

Assuming high occupancy (i.e. 5 person household) and a building airtightness of 5 air changes per hour, the classification of cases considered is as follows:

- Maintaining a bituminous felt (1F-felt) underlay (vapour resistance, of $200 \mathrm{MNs} / \mathrm{g}$ $(\mathrm{Sd}=40 \mathrm{~m})$ in all three houses but considering three different roof insulation materials with varying thickness at a constant eaves gap (10 $\mathrm{mm})$.

- Maintaining the eaves gap and insulation thickness at $10 \mathrm{~mm}$ and $300 \mathrm{~mm}$ respectively but replacing the bituminous felt with a vapour permeable underlay (VPU) known as, Roofshield of $0.09 \mathrm{MNs} / \mathrm{g}(\mathrm{Sd}=0.018 \mathrm{~m})$.

In these Cases, vapour transfer through the ceiling was considered to be by diffusion and air convection.

\subsubsection{Case 1: Effect of varying type of insulation and thickness}

This initial investigation considered the effects that would be obtained from a house with varying insulation thickness but for a constant eaves gap size of $10 \mathrm{~mm}$. In this Case, the choice of underlay was based on the actual material installed (see Table 3). As illustrated from Table 1, foam has the lowest thermal conductivity compared with the other two.

It therefore provides the best insulation for a given thickness as clearly evident in the results obtained from the simulation (Figure 7). Generally, all forms of condensation whether the air in any aspect of the assembly or on materials is unacceptable.

However, comparatively, considering all levels of insulation thickness, fibreglass (see Figure 7) seems to allow for more condensation formation (i.e. between 14 $\%$ and $27 \%$ ), while cellulose (Figure 8) accounts for a slight high increase in total energy losses (i.e. between $1 \%$ and $5 \%$ ). It must be noted that, as with most materials, condensation formation in the foam depends on its permeance. Table 5 summarizes the results obtained for all instances. 


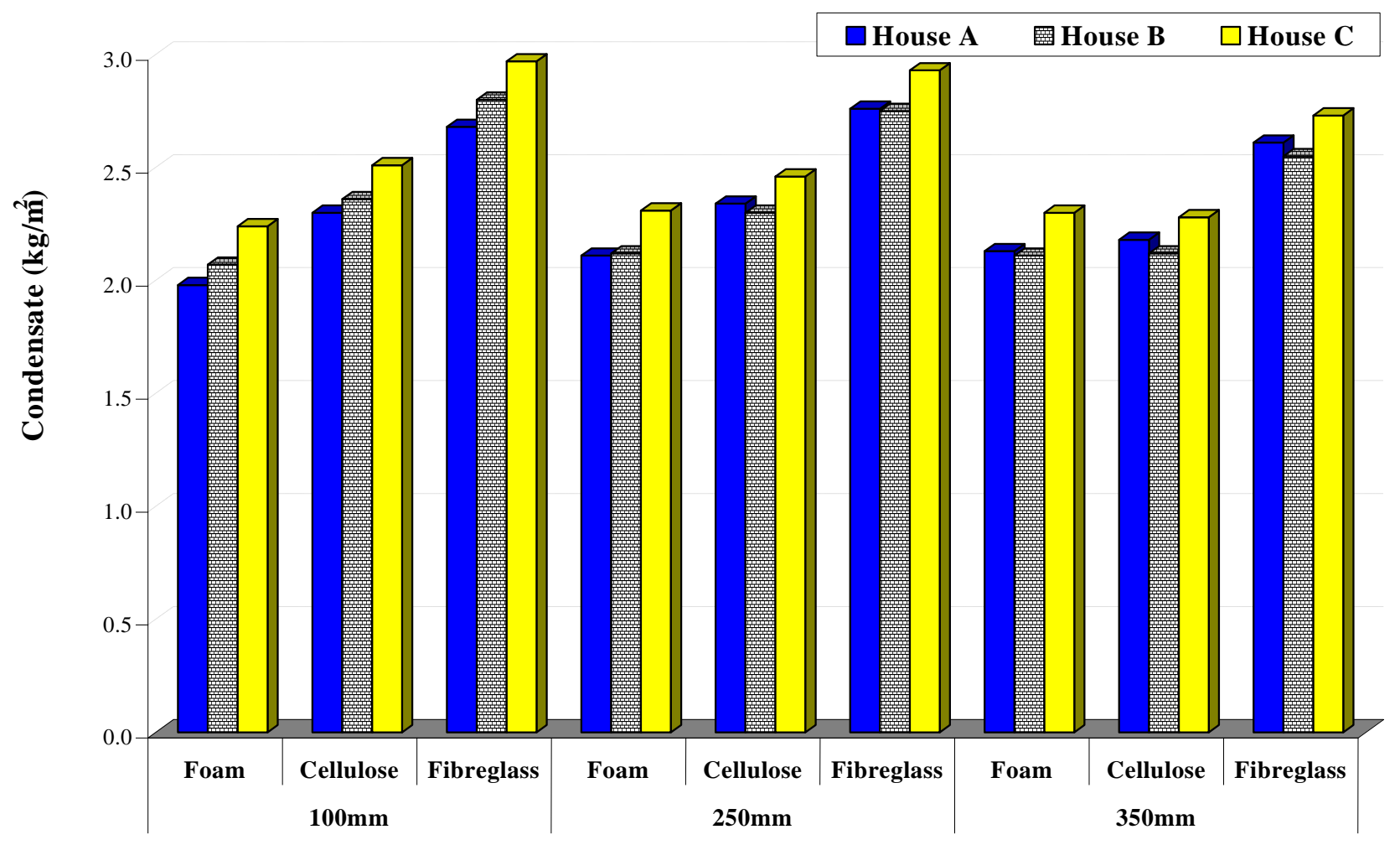

Figure 7. Trend of condensation formation that is obtained from varying insulation and thickness

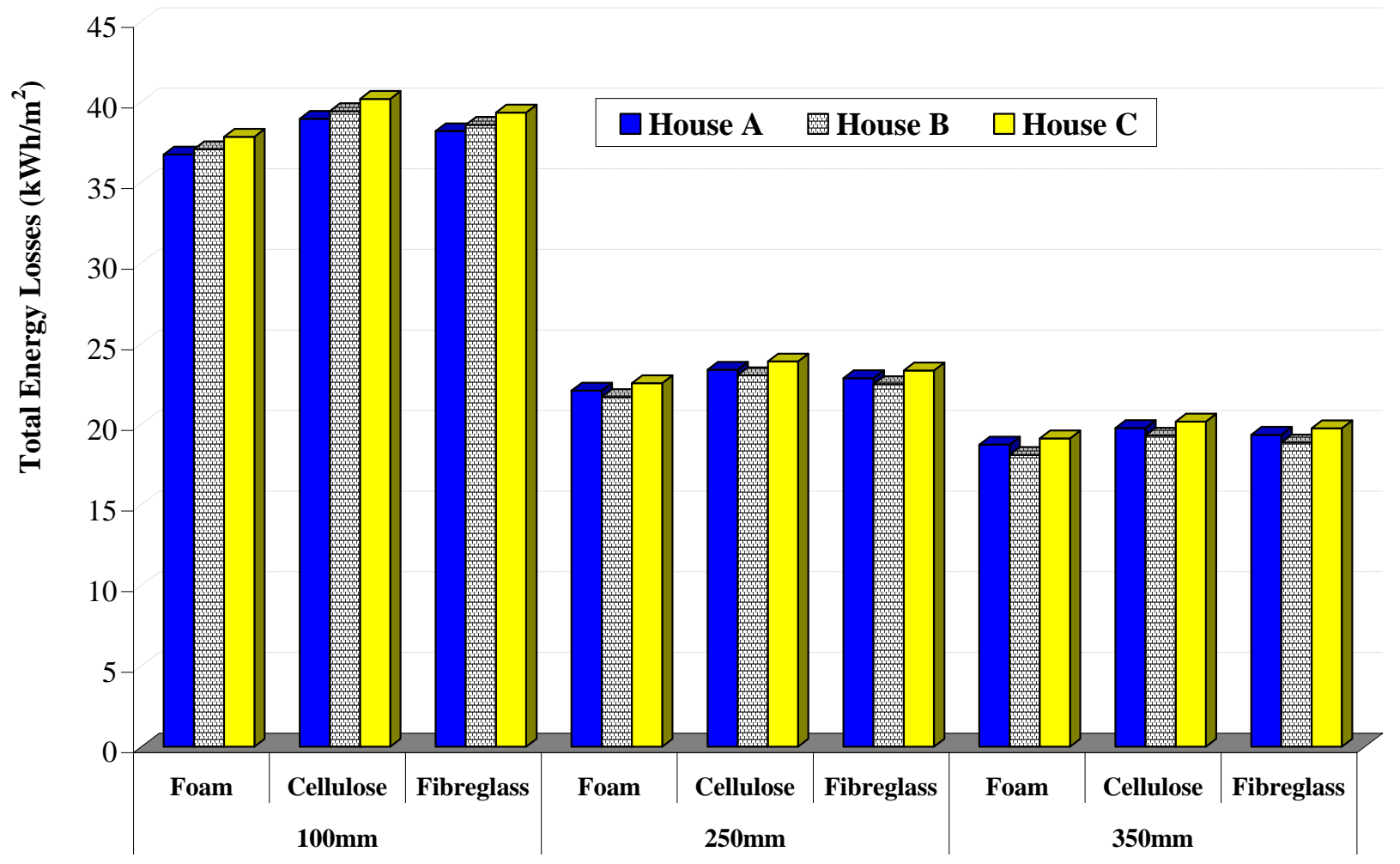

Figure 8. Energy losses due to varying insulation and thickness 
From the simulation, less insulation (i.e. $100 \mathrm{~mm}$ thick) on the ceiling would reduce the condensation formation risk in the roof space of all three houses. However, it increases the total annual energy losses across the ceiling into the roof by at least $40 \%$. The situation is reversed when the level of insulation is increased through to $350 \mathrm{~mm}$. This increase corresponds with an increase in condensation formation risks but a decrease in the overall losses through the ceiling into the roof (Table 4).
This is because though leakage losses increase steadily with insulation thickness, transmission losses decreases significantly with increasing insulation thickness (Table 4) irrespective of the roof configuration, as illustrated in Figure 9. From the results (see Figure 10), leakage losses are higher during the colder months due to the increase of warm air from the house into the roof, and with energy gains during the summer season even though it is very random with the gains balancing off the losses during such months.

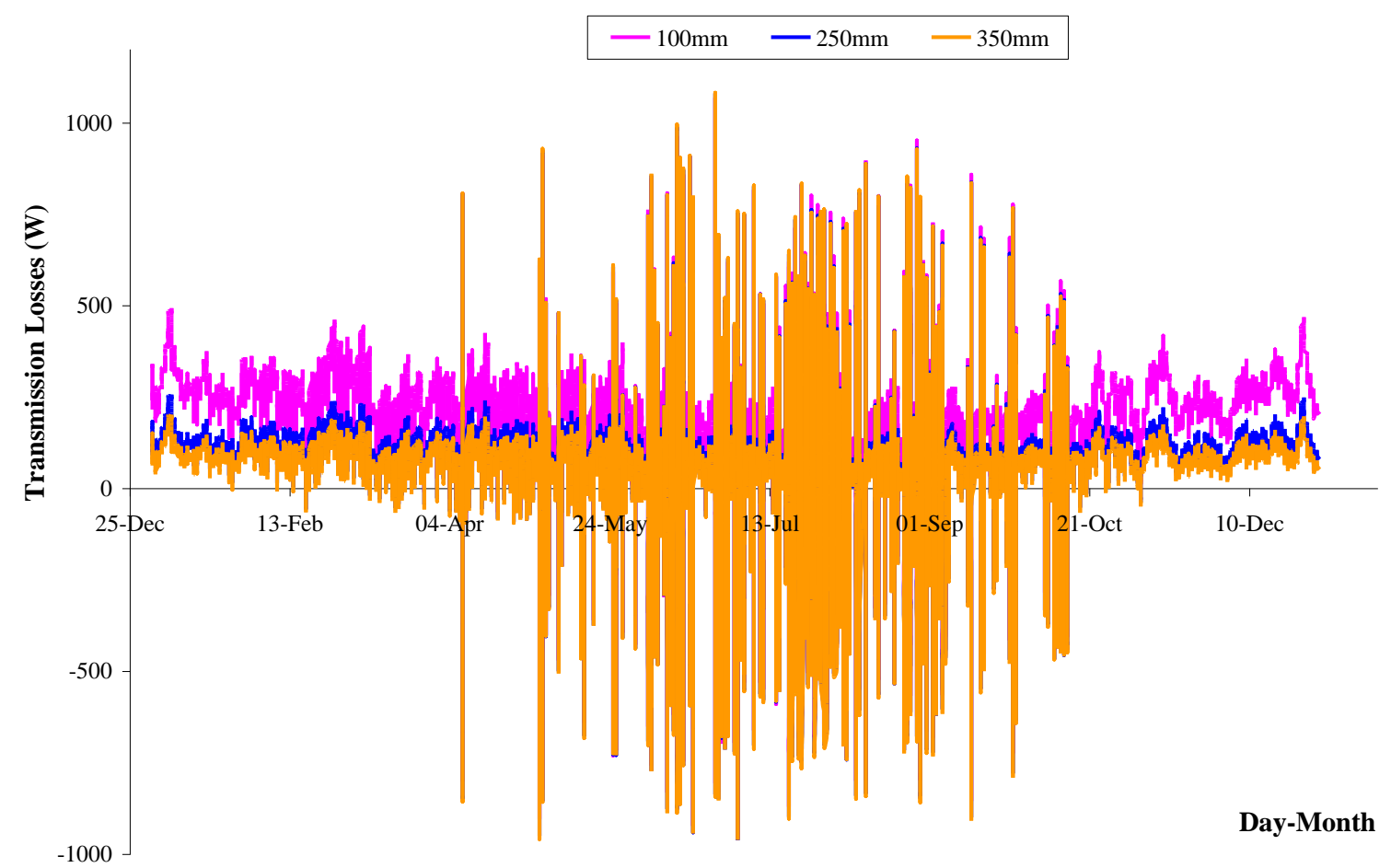

Figure 9 Transmission losses through the ceiling for varying insulation thickness 


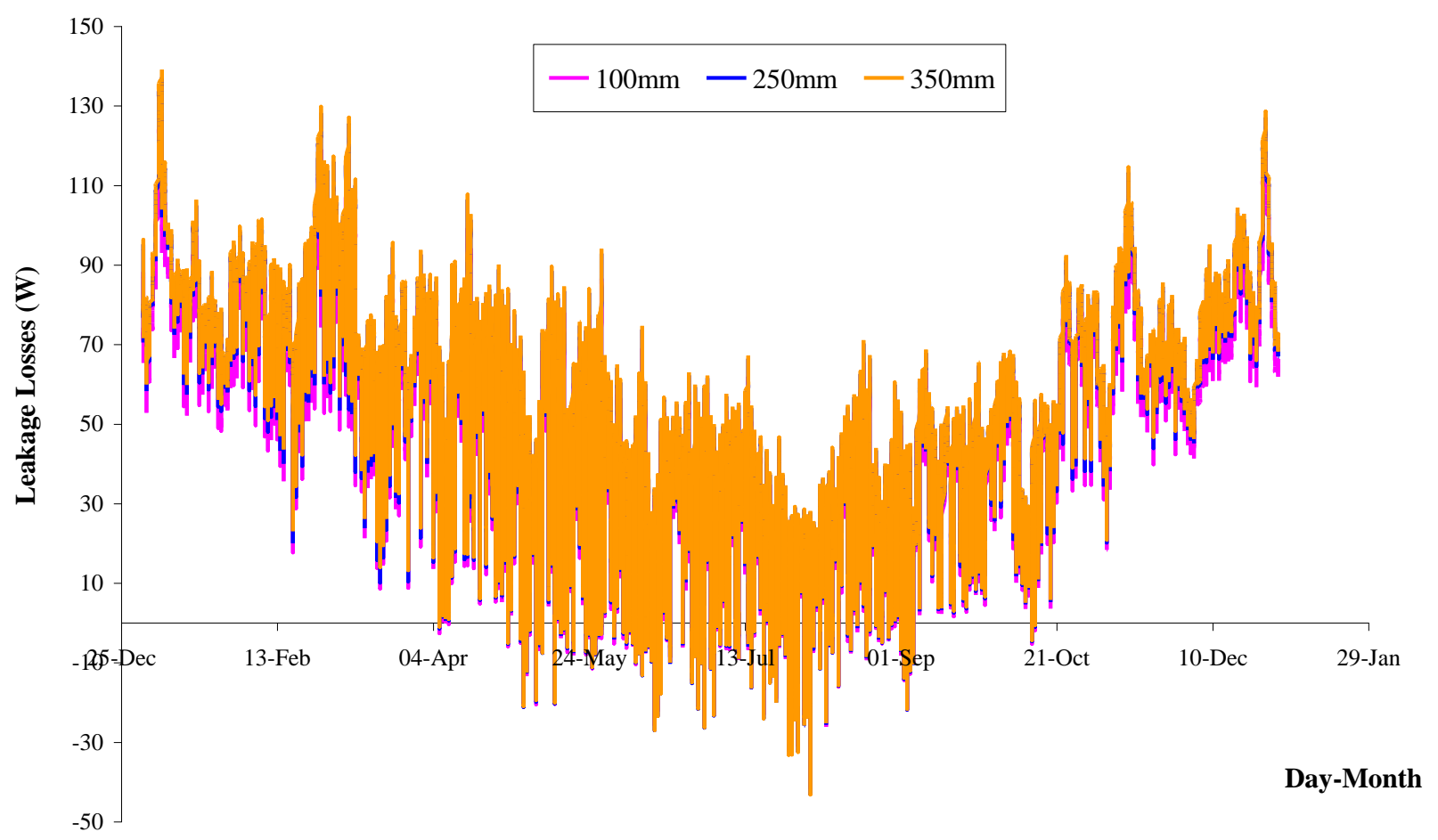

Figure 10. Leakage Losses from the house through the ceiling to the roof 
Table 4 Effects of varying insulation thickness and types on the ceiling

\begin{tabular}{|c|c|c|c|c|c|c|c|c|c|c|c|c|c|}
\hline \multirow{2}{*}{\multicolumn{2}{|c|}{$X_{h r}=20 \mathrm{~m}^{3} / \mathrm{h}$}} & \multicolumn{4}{|c|}{ FOAM INSULATION } & \multicolumn{4}{|c|}{ CELLULOSE INSULATION } & \multicolumn{4}{|c|}{ FIBREGLASS INSULATION } \\
\hline & & \multicolumn{3}{|c|}{ Losses } & \multirow[b]{2}{*}{$\begin{array}{c}\text { Condensate } \\
\mathrm{kg} / \mathrm{m}^{2}\end{array}$} & \multicolumn{3}{|c|}{ Losses } & \multirow[b]{2}{*}{$\begin{array}{c}\text { Condensate } \\
\mathrm{kg} / \mathrm{m}^{2}\end{array}$} & \multicolumn{3}{|c|}{ Losses } & \multirow[b]{2}{*}{$\begin{array}{c}\text { Condensate } \\
\mathrm{kg} / \mathrm{m}^{2}\end{array}$} \\
\hline $\begin{array}{r}\text { House } \\
\text { Type }\end{array}$ & $\begin{array}{c}\text { Insulation } \\
\text { Thickness (mm) }\end{array}$ & $\begin{array}{l}\text { Leakage } \\
\left(\mathrm{kWh} / \mathrm{m}^{2}\right)\end{array}$ & $\begin{array}{c}\text { Transmission } \\
\left(\mathrm{kWh} / \mathrm{m}^{2}\right)\end{array}$ & $\begin{array}{c}\text { Total } \\
\left(\mathrm{kWh} / \mathrm{m}^{2}\right)\end{array}$ & & $\begin{array}{l}\text { Leakage } \\
\left(\mathrm{kWh} / \mathrm{m}^{2}\right)\end{array}$ & $\begin{array}{c}\text { Transmission } \\
\left(\mathrm{kWh} / \mathrm{m}^{2}\right)\end{array}$ & $\begin{array}{c}\text { Total } \\
\left(\mathrm{kWh} / \mathrm{m}^{2}\right)\end{array}$ & & $\begin{array}{l}\text { Leakage } \\
\left(\mathrm{kWh} / \mathrm{m}^{2}\right)\end{array}$ & $\begin{array}{c}\text { Transmission } \\
\left(\mathrm{kWh} / \mathrm{m}^{2}\right)\end{array}$ & $\begin{array}{c}\text { Total } \\
\left(\mathrm{kWh} / \mathrm{m}^{2}\right)\end{array}$ & \\
\hline \multirow[t]{3}{*}{ House A } & 100 & 8.22 & 28.52 & 36.74 & 1.98 & 8.12 & 30.84 & 38.96 & 2.30 & 8.16 & 30.03 & 38.19 & 2.68 \\
\hline & 250 & 8.85 & 13.24 & 22.09 & 2.11 & 8.78 & 14.61 & 23.39 & 2.34 & 8.81 & 14.05 & 22.86 & 2.76 \\
\hline & 350 & 8.99 & 9.75 & 18.74 & 2.13 & 8.94 & 10.83 & 19.77 & 2.18 & 8.96 & 10.39 & 19.35 & 2.61 \\
\hline \multirow[t]{3}{*}{ House B } & 100 & 7.85 & 29.22 & 37.07 & 2.07 & 7.77 & 31.66 & 39.43 & 2.36 & 7.80 & 30.78 & 38.58 & 2.80 \\
\hline & 250 & 8.32 & 13.37 & 21.69 & 2.12 & 8.27 & 14.77 & 23.04 & 2.30 & 8.30 & 14.19 & 22.49 & 2.75 \\
\hline & 350 & 8.35 & 9.75 & 18.10 & 2.11 & 8.39 & 10.91 & 19.30 & 2.12 & 8.41 & 10.47 & 18.88 & 2.55 \\
\hline \multirow[t]{3}{*}{ House C } & 100 & 8.70 & 29.14 & 37.84 & 2.24 & 8.61 & 31.58 & 40.19 & 2.51 & 8.64 & 30.70 & 39.34 & 2.97 \\
\hline & 250 & 9.22 & 13.33 & 22.55 & 2.31 & 9.17 & 14.73 & 23.90 & 2.46 & 9.19 & 14.15 & 23.34 & 2.93 \\
\hline & 350 & 9.34 & 9.79 & 19.13 & 2.30 & 9.29 & 10.88 & 20.17 & 2.28 & 9.31 & 10.44 & 19.75 & 2.73 \\
\hline
\end{tabular}

Table 5 Effects of varying roof underlay for varying insulations

\begin{tabular}{|c|c|c|c|c|c|c|c|c|c|c|c|c|c|}
\hline \multirow{2}{*}{\multicolumn{2}{|c|}{$X_{h r}=20 \mathrm{~m}^{3} / \mathrm{h}$}} & \multicolumn{4}{|c|}{ FOAM INSULATION } & \multicolumn{4}{|c|}{ CELLULOSE INSULATION } & \multicolumn{4}{|c|}{ FIBREGLASS INSULATION } \\
\hline & & \multicolumn{3}{|c|}{ Losses } & \multirow[b]{2}{*}{$\begin{array}{c}\text { Condensate } \\
\mathrm{kg} / \mathrm{m}^{2}\end{array}$} & \multicolumn{3}{|c|}{ Losses } & \multirow[b]{2}{*}{$\begin{array}{c}\text { Condensate } \\
\mathrm{kg} / \mathrm{m}^{2}\end{array}$} & \multicolumn{3}{|c|}{ Losses } & \multirow[b]{2}{*}{$\begin{array}{c}\text { Condensate } \\
\mathrm{kg} / \mathrm{m}^{2}\end{array}$} \\
\hline $\begin{array}{r}\text { House } \\
\text { Type }\end{array}$ & $\begin{array}{c}\text { Roof Underlay } \\
\text { /Eaves gap }\end{array}$ & $\begin{array}{l}\text { Leakage } \\
\left(\mathrm{kWh} / \mathrm{m}^{2}\right)\end{array}$ & $\begin{array}{c}\text { Transmission } \\
\left(\mathrm{kWh} / \mathrm{m}^{2}\right)\end{array}$ & $\begin{array}{c}\text { Total } \\
\left(\mathrm{kWh} / \mathrm{m}^{2}\right)\end{array}$ & & $\begin{array}{l}\text { Leakage } \\
\left(\mathrm{kWh} / \mathrm{m}^{2}\right)\end{array}$ & $\begin{array}{c}\text { Transmission } \\
\left(\mathrm{kWh} / \mathrm{m}^{2}\right)\end{array}$ & $\begin{array}{c}\text { Total } \\
\left(\mathrm{kWh} / \mathrm{m}^{2}\right)\end{array}$ & & $\begin{array}{l}\text { Leakage } \\
\left(\mathrm{kWh} / \mathrm{m}^{2}\right)\end{array}$ & $\begin{array}{c}\text { Transmission } \\
\left(\mathrm{kWh} / \mathrm{m}^{2}\right)\end{array}$ & $\begin{array}{c}\text { Total } \\
\left(\mathrm{kWh} / \mathrm{m}^{2}\right)\end{array}$ & \\
\hline House A & Roofshield & 8.93 & 12.09 & 21.02 & 1.70 & 8.88 & 13.34 & 22.22 & 1.93 & 8.90 & 12.85 & 21.75 & 2.29 \\
\hline House B & (10mm eaves gap) & 8.39 & 11.33 & 19.72 & 1.69 & 8.35 & 12.50 & 20.85 & 1.97 & 8.37 & 12.04 & 20.41 & 2.40 \\
\hline House C & & 9.29 & 12.56 & 21.85 & 1.72 & 9.24 & 13.87 & 23.11 & 1.94 & 9.27 & 13.36 & 22.63 & 2.34 \\
\hline House A & 1F-Felt & 8.93 & 12.09 & 21.02 & 2.12 & 8.87 & 13.39 & 22.26 & 2.27 & 8.90 & 12.85 & 21.75 & 2.70 \\
\hline House B & (10mm eaves gap) & 8.38 & 11.33 & 19.71 & 2.28 & 8.34 & 12.55 & 20.89 & 2.38 & 8.36 & 12.04 & 20.40 & 2.86 \\
\hline House C & & 9.29 & 12.56 & 21.85 & 2.24 & 9.24 & 13.92 & 23.16 & 2.30 & 9.26 & 13.36 & 22.62 & 2.75 \\
\hline
\end{tabular}




\subsubsection{Case 2: Varying roof underlay}

Case 2 compares the reduction in condensation formation risks and energy benefits (if any) that would be obtained by keeping the insulation thickness constant (at $300 \mathrm{~mm}$ ), but using two roof underlay; Roofshield (a VPU) and the traditional bituminous felt (1F-Felt). To assess the effect of the underlay, the eaves ventilation gap was kept constant at $10 \mathrm{~mm}$.
Considering the results obtained (Table 5), the VPU is most effective in reducing the formation of condensation for the $10 \mathrm{~mm}$ eaves gap at the same eaves gap size for a $300 \mathrm{~mm}$ insulation thickness, though substantial amounts of condensate are formed in the roofs irrespective of the underlay installed (Figure 11). Roofshield is most effective because of its low resistance to vapour transfer.

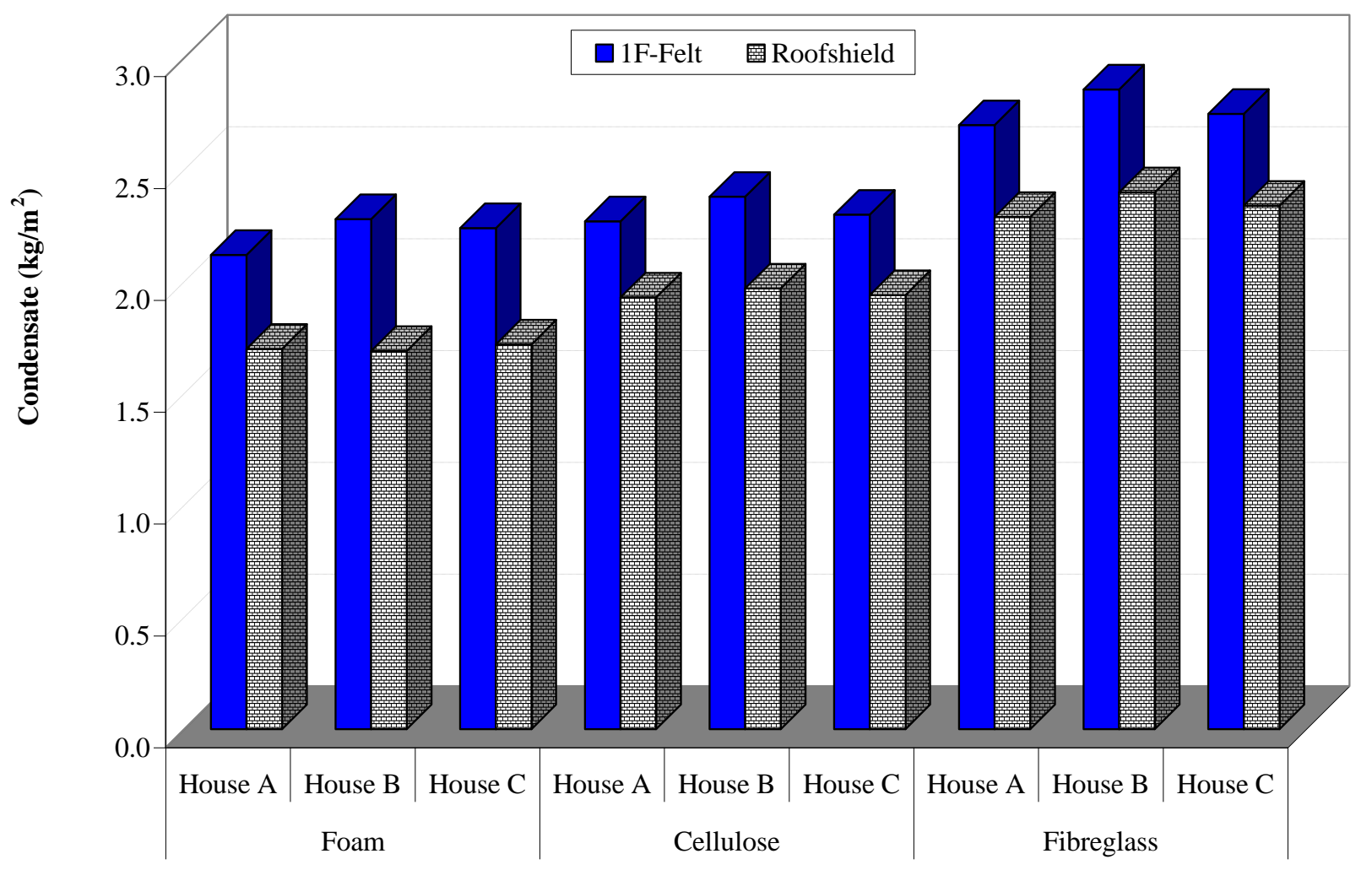

Figure 11 Trend of condensation formation that is obtained from varying roof underlay

\subsection{Conclusions}

This research has demonstrated the significance of the modelling tool in visualizing the effects of varying roof insulation. It demonstrates that both energy benefits and condensation formation risks in cold pitched roof though significantly dominated by air movements, it is somewhat influenced by the insulation material installed. The model confirms the fact that regardless of the insulation type, condensation problems would occur if there are high internal RH loads and poor loft ventilation. However, the extent of condensation formation can be influenced by the type of insulation material and its thickness. Within the context of this research, the following deductions and conclusions are made:
* The choice of insulation material is vital for gaining energy benefits as well as reducing condensation formation risks.

* In another development, increasing the insulation thickness on the ceiling, beyond the recommended levels does slightly improve the overall energy efficiency of the roof but does increase the condensation formation risks.

* Comparing the effect of the underlay, as expected the VPUs respond better to reducing the risk of condensation formation in the roof.

* Energy efficiency of the roof and hence the house is independent on the type of roof underlay installed.

The results presented in this paper provide insight into the effects of airflows into cold pitched roofs. In all 
aspects of this investigation, the analysis and results supports the fact that, the most ideal approach to improve the energy benefits and reduce condensation formation risks assuming the building envelop is airtight, is to introduce sufficient ventilation into the loft space. It goes without saying that the choice of insulation thickness is very significant. As a result stipulating the thickness of roof insulation must be based on several factors including the configuration and the pitch of the roof, and possible insulation of the whole building.

This finding is supported by the German standard, DIN 18531. According to the standard, the inclination of the roof significantly influences the type and design of the chosen roof insulation (www.basf.de).

One should note that, there is a clear differentiation between the reduction in energy consumption, the condensation of atmospheric humidity and the condensation of humidity coming through the roof from the interior of the dwellings.

In this regard, it must be noted that, there is a clear distinction between two key parameters; the response of the insulation material to the condensing vapours is one thing, the choice of a "waterproof" insulation material (where applicable) is another. For instance as demonstrated in this research, fibreglass works well in letting water vapour from the interior to pass through its fibrous structure and it can withstand condensation and regain its properties when drying. Similarly, hydrophobic foamy materials, such as types: PUR, PIR, XPS can withstand condensation, but as they are not allowing rising vapours to pass through their structure, this may lead to condensation formation in the interior. It must be noted that this concept and effects in relation to the categories of foam was not explored in this research.

In addition, other aspects, like fire safety and environmental friendliness of these insulation materials have not been considered in this research bur are worth noting as a significant parameter for further studies.

\section{References}

British Standards, BS EN 15026 (2007). Hygrothermal performance of building components and building elements. Assessment of moisture transfer by numerical simulation. National Standards Body, BSI British Standards, London.
Essah, E.A. and Sanders, C.H. (2006).Heat and moisture transport between houses and cold lofts - a combination of convection and diffusion. International Energy Agency, Annex 41: Whole building Heat, Air and Moisture response MOIST-ENG, Kyoto-Japan , pp 1-12.

Essah, E. A. and Sanders, C.H (2010) Principles and calibration of solid phase microextraction fibre (passive sampler) for measurements of airflow and air infiltration in dwellings. International Journal of Ventilation, 9 (2). pp. 115-130. ISSN 1473-3315

Essah, E.A., Sanders, C.H., Galbraith, G.H., and McLean, R.C.. Airflow between houses and their roofs (2006). Proceedings of the $3^{\text {rd }}$ international Building Physics Conference, Concordia University, MontrealCanada. Research in Building Physics and Building Engineering. ISBN 0-415-41675-2, pp. 737-744.

Essah, E.A., Sanders, C.H., Baker, P. Galbraith, G.H., and Sasic Kalagasidis, A. (2008). Simulating the energy benefits and reduction in condensation formation that is obtained from houses with Cold Pitched Roofs. Proceedings of the $8^{\text {th }}$ Nordic Symposium on Building Physics, Technical University of Denmark in Lyngby, Denmark., pp 793-799.

Essah, E.A., Sanders, C.H., Baker, P. and Sasic Kalagasidis, A. (2009) Condensation and moisture transport in cold roofs: effect of roof underlay. Journal of Building Research and Information. Vol 37 (2), pp. 117-128.

Essah E.A. (2009) Modelling and measurements of airflow and ventilation within domestic pitched roofs. $\mathrm{PhD}$ Thesis. Glasgow Caledonian University, Glasgow, UK.

Hagentoft, C.E. (2001). Introduction to Building Physics. Lund-Sweden, Studentlitteratur. pp. 1-5.

Harvey, L.D.D. (2010). Energy and the New Reality 2 Carbon-free Energy Supply, Earthscan Publishers Ltd. p 127-129

Hokoi, S. and Kumaran, M.K. (1993) Experimental and Analytical Investigations of Simultaneous Heat and Moisture Transport through Glass Fiber Insulation. Journal of Building Physics., pp 263292

Holm, A and Lengsfeld, K. (2007) Hygrothermal Performance of Ventilated Cold Roofs an Experimental Study. Proceedings in the $11^{\text {th }}$ Canadian Conference on 
Building Science and Technology, Banff, Alberta (http://bricks-and-brome.net/20c11.pdf)

Kaufmann, A., Künzel1, H.M. and Radoń,J (2006)1Preventing Moisture Problems in Retrofitted Pitched Roofs. ACTA Scientiarum Polonorum, Architectura 5 (1), pp 69-79

Kumaran, K., (1996). Heat, air, and moisture transfer in insulated envelope parts: Task 3-Material Properties. International Energy Agency (IEA), Annex 24, Final Report, Vol.3.

Liddament, M.W,(1986). Air infiltration calculation techniques-An application guide. Annex V, Air Infiltration and ventilation Centre. ISBN 0-94607585-9, pp 39

Loomans, M.G.L.C. (1998).The measurement and simulation of indoor airflow-PhD Thesis- Technical University, Eindhoven, ISBN 90-6814-085-X, pp. 1-6, 29.

McMullan, R. (2007). Environmental Science in Buildings, Palgrave MacMillan Publishers, $6^{\text {th }}$ Edition, pp14-15

Petherick, D. (2001). Ventilated and unventilated cold pitched roofs: Draft Good Building Guide. DTLR Building regulations Division- Project Report number 16340, pp. 1-15.

Sanders, C.H. (1982) Air movement in houses: a new approach. Journal of Building Research and practice, CI/SFB 81 (57), pp. 160-175.

Sanders, C.H., (1996). Heat, Air and Moisture transfer through new and retrofitted insulated envelope parts (Hamite), IAE Annex 24: Final Report, Task 2: Environmental Conditions, Vol 2, pp. 77-89.

Sanders, C.H. (2006) Modelling condensation and airflow in pitched roofs-Building Research Establishment (BRE) information paper, IP 05/06. BRE Press, Garston, Watford-UK. ISBN 1-86081912-5, pp. 1-7.

Santamouris, M. et al. (1998) Natural ventilation in buildings: a design handbook. London-UK, James and James (Science Publisher) Ltd.pp. 1-4.

Stirling, C. (2002) Thermal Insulation: avoiding risk- A good practice guide supporting building regulation requirements. Building Research Establishment (BRE), Scotland, BR 262, pp.15.

Walker, I.S., Forest, T.W. and Wilson, D.J. (2005). An attic-interior infiltration and inter-zone transport model of a house, Building and Environment, 40 (5), pp 701718

Loft insulation

Available:

http://www.energysavingtrust.org.uk/business/Business /Energy-Saving-Trust-Recommended/Productcriteria/Insulation/Loft-insulation

[Cited 16 October 2010]

Matlab - www.matworks.com

Building fabric: Energy saving techniques to improve the efficiency of building structures

Available: http://www.carbontrust.co.uk/cut-carbonreduce-costs/products-services/technology

advice/Pages/building-fabric.aspx

[Cited 20 November 2010]

How to implement roof insulation

Available:

http://www.carbontrust.co.uk/Publications/pages/public ationdetail.aspx?id=CTL064

[Cited 20 November 2010]

National Housing Building Council (NHBC) (2006)

NHBC's Technical News Letter - Standards Extra,

36.September.

Available:

http://www.nhbcbuilder.co.uk/NHBCpublications/Liter atureLibrary/Technical/StandardsExtra/filedownload,27 506,en.pdf)

[Cited 8 February 2012].

Proposals for amending Part L and Part $\mathrm{F}$ of the Building Regulations - Consultation Vol 2: Proposed technical guidance for Part L

Available: http://www.communities.gov.uk

[Cited November 2011]

Roof Insulation, Styrodur ${ }^{\circledR}$ C Europe's green insulation Available at: http://www.basf.de/basf2/img/produkte/kunststoffe/styr odur/downloads/EN/Styrodur_Roof_Insulation.pdf [Cited 10 June 2012] 